\title{
Article \\ Effects of Nitrogen Fertilizer Management on Stalk Lodging Resistance Traits in Summer Maize
}

\author{
Juan Zhai, Yuanmeng Zhang, Guoqiang Zhang $\left.{ }^{(}\right)$, Ming Tian, Ruizhi Xie, Bo Ming ${ }^{(0)}$, Peng Hou, Keru Wang, \\ Jun Xue *(i) and Shaokun Li
}

check for

updates

Citation: Zhai, J.; Zhang, Y.;

Zhang, G.; Tian, M.; Xie, R.; Ming, B.; Hou, P.; Wang, K.; Xue, J.; Li, S. Effects of Nitrogen Fertilizer Management on Stalk Lodging Resistance Traits in Summer Maize. Agriculture 2022, 12, 162. https://doi.org/10.3390/ agriculture12020162

Academic Editor: Lorenzo Barbanti

Received: 4 January 2022

Accepted: 19 January 2022

Published: 24 January 2022

Publisher's Note: MDPI stays neutral with regard to jurisdictional claims in published maps and institutional affiliations.

Copyright: (C) 2022 by the authors. Licensee MDPI, Basel, Switzerland. This article is an open access article distributed under the terms and conditions of the Creative Commons Attribution (CC BY) license (https:// creativecommons.org/licenses/by/ $4.0 /)$.
Institute of Crop Sciences, Chinese Academy of Agricultural Sciences, Key Laboratory of Crop Physiology and Ecology, Ministry of Agriculture and Rural Affairs, Beijing 100081, China; zhaijuan823@163.com (J.Z.); zhangym0113@163.com (Y.Z.); zgq528208@163.com (G.Z.); TMing3885@163.com (M.T.); xieruizhi@caas.cn (R.X.); mingbo@caas.cn (B.M.); houpeng@caas.cn (P.H.); wangkeru@caas.cn (K.W.); lishaokun@caas.cn (S.L.)

* Correspondence: xuejun5519@126.com; Tel.: +86-10-82108595

\begin{abstract}
Stalk lodging in Huang-Huai-Hai summer maize is a serious problem that reduces maize yields and precludes the use of mechanical grain harvesting equipment. In order to determine the effect of nitrogen management on the lodging resistance of maize stalk, three nitrogen application rates of 150, 250, and $350 \mathrm{~kg} \mathrm{ha}^{-1}$ (denoted as N150, N250, and N350), and different nitrogen application periods (sowing, 6-leaf, 12-leaf, silking) were set. Plant morphology, stalk mechanical strength, total carbohydrate, nitrogen content, and yield were measured in the different treatments. The results showed that as the nitrogen application rate increased and nitrogen application was postponed, the stalk breaking force, plant height, ear height, center of gravity height, stalk basal internode diameter, rind penetration strength, content of carbohydrate, and total $\mathrm{N}$ of maize stalk also increased. The stalk lodging resistance was improved by the increased nitrogen application rate and postponed nitrogen application by increasing the stalk material accumulation and mechanical strength. The nitrogen application rates had no significant effect on grain yield. Under N250 and N350, the treatments with no base fertilizer significantly decreased the kernel number per ear, reflected in some in grain yield. In summary, under the conditions of integrated water and fertilizer drip irrigation and fractional nitrogen fertilizer applications, increased nitrogen fertilizer input can stimulate the growth of high-quality maize populations, significantly improve stalk lodging resistance in the early growth stage, delay stalk senescence, improve stalk strength and influence stalk composition in later growth stages. Based on the summer maize grain yield and stalk lodging resistance, under N250 treatment, a base fertilizer combined with topdressing at the 12-leaf and silking stages was beneficial to the growth of summer maize.
\end{abstract}

Keywords: summer maize; nitrogen application rate; fertilization period; lodging resistance; stalk strength; yield

\section{Introduction}

As maize is the largest food crop in China and the world, the stable yield of maize is highly relevant to national food security [1]. Nitrogen fertilizers are the "food" of food crops. About $48 \%$ of the world's population depends on fertilizers to produce their food, of which nitrogen fertilizers account for 30-50\% [2]. Nitrogen fertilizer application primarily affects maize growth and yield [3-5]. Insufficient or improper nitrogen fertilizer application can cause nitrogen stress throughout the maize growth period, dwarfed plants, premature leaf senescence, and low yields [6,7]. When applied appropriately, nitrogen fertilizer can increase the photosynthetic capacity of maize plants in the middle and late growth stages and prolong the functional period of the middle and lower leaves, which significantly contributes to increased yields of maize [8]. The time between the six-leaf and silking stages of summer maize is crucial for absorbing nitrogen, phosphorus, and potassium; during 
this period the nutrient absorption rate is rapid and nutrient accumulation is high [9]. Therefore, a sufficient supply of nutrients during this period should be considered in production management strategies. The period between the six-leaf and silking stages is a prime time for the fertilization of super-high-yield summer maize. Interestingly, super-high-yield summer maize continues to absorb nutrients after silking. Appropriate topdressing to ensure adequate nutrient supply and promote summer maize filling during the silking period may increase summer maize yields [9]. Research shows that with nitrogen application rates of 210 and $350 \mathrm{~kg} \mathrm{ha}^{-1}$, postponed nitrogen fertilizer application can promote nitrogen absorption and accumulation in the later growth stages of maize, and significantly improve maize yields and nitrogen use efficiency [10,11]. While an appropriate amount of nitrogen fertilizer can increase yield, as nitrogen application increases maize yields initially increase, then eventually begin to decrease $[12,13]$. The rational application of nitrogen fertilizer based on its effect on crop productivity has become a primary focus of agricultural production research [14].

Lodging is an important factor causing yield loss during maize production [15-17]. Not only does lodging reduce crop yield, but it also reduces harvest efficiency and maize quality and increases harvest costs [15,18]. Maize lodging includes the lodging of both roots and stalks; however, yield reductions result more often from stalk lodging [19]. Stalk lodging mainly occurs in the basal internodes of aboveground parts [20], especially during the grain filling stage when ear size increases, affecting the maize plant's center of gravity. Additionally, carbohydrates in the stalk are continuously transported to the grain, resulting in the decline of stalk quality and increased risk of stalk lodging [15]. Therefore, finding ways to reduce the risk of lodging and improve the stalk quality of maize plants during the filling stage is essential to enhance maize production.

Stalk lodging resistance is affected by multiple factors such as genotype, plant morphology, stalk quality, pests and diseases, environmental factors, and water and fertilizer management $[15,21]$. Studies have shown that improper application of nitrogen fertilizers can result in crop overgrowth, increased plant height, slender internodes, and poor stalk fullness, which increase the risk of lodging [22]. Another study previously reported that the lodging rate of maize is significantly negatively correlated with nitrogen content in the stalk [23]. The application of nitrogen fertilizer can effectively improve the lodging resistance of maize plants [24], primarily by promoting the accumulation of total dry matter in the form of cellulose, lignin, and total nitrogen in the stalk during the maize filling period, thereby improving the mechanical strength of the stalk [17]. Postponing nitrogen application is an effective way to enhance maize nitrogen use efficiency and yield [10,25]. However, how this practice affects the lodging resistance of maize stalks is scarcely reported.

In modern maize production practices, the mechanical grain harvest is the primary harvesting method employed [26]. In the field, stalk stability after physiological maturity is an important factor used to measure whether it is suitable for mechanical harvesting [27,28]. At present, research on the influence of nitrogen fertilizer management on maize primarily focuses on how to increase yield and nitrogen utilization efficiency [9-12,25], and studies on the effects of stalk development and lodging resistance have been focused on the period between the silking stage and maturity $[16,22,23,29-31]$. Therefore, we hypothesize that nitrogen management can improve maize lodging resistance in later growth stages by increasing dry matter accumulation in maize stalk.

This study explores the effects of nitrogen fertilizer management on lodging resistance and maize yields regarding plant mechanical characteristics, agronomic characteristics, stalk carbohydrate accumulation characteristics, yield composition, dry matter, and leaf area index across set levels postponing nitrogen application. This study will provide a theoretical basis for nitrogen fertilizer management in Huang-Huai-Hai summer maize production. 


\section{Materials and Methods}

\subsection{Experimental Station}

The experiment was conducted from 2018 to 2019 at the Henan Xinxiang Comprehensive Experimental Base $\left(35^{\circ} 10^{\prime} \mathrm{N}, 113^{\circ} 47^{\prime} \mathrm{E}\right)$ in the Institute of Crop Science at the Chinese Academy of Agricultural Sciences. The test base is located in a warm-temperate, continental monsoon climate zone, with an annual average temperature of $14{ }^{\circ} \mathrm{C}$, and yearly precipitation reaching $573.4 \mathrm{~mm}$, mainly in July and August. The weather data was recorded by the Watch Dog Weather Station data loggers (Spectrum Technologies, Inc., Washington, DC, USA). The monthly precipitation, sunshine hours, and average temperature are shown in Table 1 . The soil in the test field is clay loam, with the following features: total nitrogen of $1.2 \mathrm{~g} \mathrm{~kg}^{-1}$, available phosphorus $12.9 \mathrm{mg} \mathrm{kg}^{-1}$, available potassium $139.1 \mathrm{mg} \mathrm{kg}^{-1}$, organic matter $17.8 \mathrm{~g} \mathrm{~kg}^{-1}$, $\mathrm{pH} 7.6$.

Table 1. Precipitation, sunshine hours, and average temperature during the summer maize growth period in 2018 and 2019.

\begin{tabular}{ccccccc}
\hline \multirow{2}{*}{ Month } & \multicolumn{2}{c}{ Precipitation $(\mathbf{m m})$} & \multicolumn{2}{c}{ Sunshine Hours $(\mathbf{h})$} & \multicolumn{2}{c}{ Average Temperature $\left({ }^{\circ} \mathbf{C}\right)$} \\
\cline { 2 - 7 } & $\mathbf{2 0 1 8}$ & $\mathbf{2 0 1 9}$ & $\mathbf{2 0 1 8}$ & $\mathbf{2 0 1 9}$ & $\mathbf{2 0 1 8}$ & $\mathbf{2 0 1 9}$ \\
\hline June & 122.9 & 38.2 & 319.5 & 311 & 27.2 & 27.8 \\
July & 152.3 & 8.3 & 319 & 326.5 & 28.9 & 28.7 \\
August & 3.8 & 54.3 & 304 & 295 & 28 & 26.1 \\
September & 92.3 & 34.3 & 244 & 248.5 & 21.5 & 21.6 \\
October & 1.4 & 40.8 & 261.5 & 222 & 16.2 & 16.3 \\
\hline
\end{tabular}

\subsection{Experimental Design}

Experiments were conducted using the maize variety Jingnongke 728 , an approved cultivar for mechanical grain harvesting. Maize was planted at 75,000 plants ha ${ }^{-1}$, in equal rows of $60 \mathrm{~cm}$. Three application rates $\left(150,250\right.$, and $\left.350 \mathrm{~kg} \mathrm{ha}^{-1}\right)$ of pure nitrogen were set, which were labeled as N150, N250, and N350, respectively. Under N150 treatment, $150 \mathrm{~kg} \mathrm{~N} \mathrm{ha}{ }^{-1}$ was applicated at sowing stage. Five nitrogen split application treatments were set under N250, the treatments applied were as follows: (1) Nft, $150 \mathrm{~kg} \mathrm{~N} \mathrm{ha}^{-1}$ and $100 \mathrm{~kg} \mathrm{~N}^{-1}$ were applicated at sowing and 6-leaf stages, respectively; (2) Nfzt, $150 \mathrm{~kg} \mathrm{~N} \mathrm{ha}^{-1}$ and $100 \mathrm{~kg} \mathrm{~N} \mathrm{ha}^{-1}$ were applicated at sowing and 12-leaf stages, respectively; (3) Nfzzt, $150 \mathrm{~kg} \mathrm{~N} \mathrm{ha}^{-1}$ and $100 \mathrm{~kg} \mathrm{~N} \mathrm{ha}^{-1}$ were applicated at sowing and silking stages, respectively; (4) Nzft, $150 \mathrm{~kg} \mathrm{~N} \mathrm{ha}^{-1}$ and $100 \mathrm{~kg} \mathrm{~N} \mathrm{ha}^{-1}$ were applicated at 6-leaf and 12-leaf stages, respectively; (5) Nzfzt, $150 \mathrm{~kg} \mathrm{~N} \mathrm{ha}^{-1}$ and $100 \mathrm{~kg} \mathrm{~N} \mathrm{ha}^{-1}$ were applicated at 6-leaf and silking stages, respectively. Four nitrogen split application treatments were set under N350, the treatments applied were as follows: (1) Nftt, $150 \mathrm{~kg} \mathrm{~N} \mathrm{ha}^{-1}, 100 \mathrm{~kg} \mathrm{~N} \mathrm{ha}^{-1}$ and $100 \mathrm{~kg} \mathrm{~N} \mathrm{ha}^{-1}$ were applicated at sowing, 6-leaf, and 12-leaf stages, respectively; (2) Nftzt, $150 \mathrm{~kg} \mathrm{~N} \mathrm{ha}^{-1}, 100 \mathrm{~kg} \mathrm{~N} \mathrm{ha}^{-1}$ and $100 \mathrm{~kg} \mathrm{~N} \mathrm{ha}^{-1}$ were applicated at sowing, 6-leaf, and silking stages, respectively; (3) Nfztt, $150 \mathrm{~kg} \mathrm{~N} \mathrm{ha}^{-1}, 100 \mathrm{~kg} \mathrm{~N}^{-1}$ and $100 \mathrm{~kg} \mathrm{~N} \mathrm{ha}^{-1}$ were applicated at sowing, 12-leaf, and silking stages, respectively; (4) Nzftt, $150 \mathrm{~kg} \mathrm{~N} \mathrm{ha}^{-1}$, $100 \mathrm{~kg} \mathrm{~N} \mathrm{ha}^{-1}$ and $100 \mathrm{~kg} \mathrm{~N}$ ha $^{-1}$ were applicated at 6-leaf, 12-leaf, and silking stages, respectively. Table 2 outlines the details of nitrogen treatment. Across the study region, the nitrogen application rate was $350 \mathrm{~kg} \mathrm{ha}^{-1}$, and application was carried out in the sowing period. The area of each plot was $42 \mathrm{~m}^{2}$, with three repetitions. An integrated water and fertilizer drip irrigation system was used to control the precise amount of nitrogen fertilizer delivered; total irrigation over the whole growth was $110 \mathrm{~mm}$. Before sowing, $90 \mathrm{~kg} \mathrm{ha}^{-1} \mathrm{P}_{2} \mathrm{O}_{5}$ and $90 \mathrm{~kg} \mathrm{ha}^{-1} \mathrm{~K}_{2} \mathrm{O}$ were applied as base fertilizers. The same methods employed in local field management programs were used to achieve adequate disease, pest, and weed control. 
Table 2. Fertilization methods and period under different nitrogen application rates.

\begin{tabular}{|c|c|c|c|c|c|}
\hline \multirow{2}{*}{$\begin{array}{l}\text { Nitrogen Application Rate } \\
\qquad\left(\mathrm{kg} \mathrm{ha}^{-1}\right)\end{array}$} & \multirow{2}{*}{ Fertilization Methods } & \multicolumn{4}{|c|}{ Nitrogen Application Period and Amount (kg ha $\left.{ }^{-1}\right)$} \\
\hline & & Sowing & 6-Leaf (V6) & 12-Leaf (V12) & Silking (R1) \\
\hline 150 & $\mathrm{Nf}$ & 150 & 0 & 0 & 0 \\
\hline \multirow{5}{*}{250} & $\mathrm{Nft}$ & 150 & 100 & 0 & 0 \\
\hline & Nfzt & 150 & 0 & 100 & 0 \\
\hline & Nfzzt & 150 & 0 & 0 & 100 \\
\hline & $\mathrm{Nzft}$ & 0 & 150 & 100 & 0 \\
\hline & Nzfzt & 0 & 150 & 0 & 100 \\
\hline \multirow[t]{4}{*}{350} & $\mathrm{Nftt}$ & 150 & 100 & 100 & 0 \\
\hline & Nftzt & 150 & 100 & 0 & 100 \\
\hline & Nfztt & 150 & 0 & 100 & 100 \\
\hline & $\mathrm{Nzftt}$ & 0 & 150 & 100 & 100 \\
\hline
\end{tabular}

Note: " $\mathrm{z}$ " refers to the nitrogen application rate being zero, " $\mathrm{f}$ " refers to the nitrogen application rate being $150 \mathrm{~kg} \mathrm{ha}^{-1}$, " $\mathrm{t}$ " refers to the nitrogen application rate being $100 \mathrm{~kg} \mathrm{ha}^{-1}$, e.g., $\mathrm{Nf}$ refers to nitrogen application rate being $150 \mathrm{~kg} \mathrm{ha}^{-1}$ at sowing stage; Nfzt refers to nitrogen application rate being 150,0 , and $100 \mathrm{~kg} \mathrm{ha}^{-1}$ at sowing, 6-leaf, and 12-leaf stages, respectively; Nzftt refers to the nitrogen application rate being 0,150, 100, and $100 \mathrm{~kg} \mathrm{ha}^{-1}$ at sowing, 6-leaf, 12-leaf, and silking stages, respectively.

\subsection{Measurements and Methods}

\subsubsection{Stalk Breaking Force}

At the silking, maturity, and harvest stages of maize growth, five representative plants were randomly selected from each treatment in the field. The stalk breaking force (SBF) was measured by pushing the plant over at the ear position using a YYD-1 stalk strength instrument (Zhejiang Top Instrument Co., Ltd., Hangzhou, China). The thrust direction was always perpendicular to the direction of the stalk during the measurement. Before the measurement, the soil around the roots was solidified to avoid root lodging [28].

\subsubsection{Plant Morphology}

After measuring the SBF, the plant height, ear height, center of gravity height, and diameter of the third elongation internode above the soil were measured [28]. To measure the center of gravity height: cut the plant horizontally along the ground, and lay it horizontally (with ears, leaves, and sheaths), and lift it horizontally with the index finger to keep it balanced without inclination. The distance between the finger and the stalk base during balance is the height of the center of gravity. The ear ratio and the gravity ratio were calculated using the following formulas:

$$
\text { Ear ratio }=\text { Ear height } / \text { Plant height }
$$

$$
\text { Gravity ratio = center of gravity height/Plant height }
$$

\subsubsection{Rind Penetration Strength of Internodes}

After measuring the plant morphology, a measuring head with a cross-sectional area of $1 \mathrm{~mm}^{2}$ was installed at the top interface of the YYD-1 stalk strength meter and used to determine the rind penetration strength (RPS) of the third elongation internode above the soil [32]. The measurement was carried out on the long axis in the middle of the internode, and the side head was continuously moved down slowly and uniformly during the measurement.

\subsubsection{Carbohydrate and Total N Content of Internodes}

At the harvest stage, after measuring the RPS, the lengths of the third internode were measured with a ruler, then put in an oven at $105^{\circ} \mathrm{C}$ for $30 \mathrm{~min}$, then dried at $65^{\circ} \mathrm{C}$ to a constant weight. The dry weight was measured and used to calculate the dry weight per unit length (DWUL) according to the following formula: DWUL $\left(\mathrm{mg} \mathrm{cm}^{-1}\right)=$ dry weight $(\mathrm{g}) /$ length $(\mathrm{cm}) \times 1000$. 
The third internode samples were crushed and passed through a $1 \mathrm{~mm}$ mesh sieve. The Hanon-K9840 automatic Kjeldahl nitrogen analyzer (Shandong Haineng Scientific Instrument Co., Ltd., Dezhou, China) was used to determine the total nitrogen content at harvest [33]. The A200i semi-automatic fiber analyzer (ANKOM company, Macedon, NY, USA) and filter bags were used according to the manufacturer's instructions to determine the cellulose and lignin content of the samples at harvest [34]. The per-unit-length contents of structural carbohydrate and total nitrogen in the third internode were calculated as follows: per-unit-length content (structural carbohydrate or total $\mathrm{N})\left(\mathrm{mg} \mathrm{cm}^{-1}\right)=$ DWUL $\left(\mathrm{mg} \mathrm{cm}^{-1}\right) \times$ content (cellulose lignin, or total nitrogen) percentage $(\%)$.

\subsubsection{Leaf Area Index}

At the silking and maturity stages, after measuring the SBF, each leaf's length (L) and maximum leaf width $(\mathrm{W})$ were measured. The leaf area (LA) was calculated as follows: $\mathrm{LA}=0.75 \times \mathrm{L} \times \mathrm{W}$. The leaf area index $(\mathrm{LAI})$ was calculated by multiplying the average LA per plant-by-plant density [35].

\subsubsection{Plant Dry Weight}

The stalks, leaves, sheaths, tassels, and ears of sample maize plants were heated at $105^{\circ} \mathrm{C}$ for $30 \mathrm{~min}$, dried at $80^{\circ} \mathrm{C}$ to a constant weight, and then weighed.

\subsubsection{Grain Yield}

Once maize plants reached maturity, each plot was harvested and tested. From each plot, plants from 2 rows in a $5 \mathrm{~m}$ area were selected for yield determination, and 20 ears were selected for indoor tests. The final yield is calculated based on $14 \%$ moisture. Measurements were taken in triplicate for each plot.

\subsection{Data Analysis}

SPSS 21.0 software (IBM Inc., Amonk, NY, USA) was used for data analysis. Statistical analysis was preceded by tests for normality and homogeneity of variances. The differences in plant morphology, carbohydrate accumulation, and nitrogen content were analyzed by univariate analysis of variance. The least significant difference (LSD) test at the $p=0.05$ significance level was used to determine significant differences. Pearson's correlations were used to determine the relationship between RPS and the cellulose, lignin, and total nitrogen contents of the third internode samples. Figures were plotted using Origin 2022 software (OriginLab, Northampton, MA, USA).

\section{Results and Analysis}

\subsection{Stalk Breaking Resistance}

The nitrogen rate and postponed treatments had significant effects on the breaking resistance of maize stalks (Figure 1). The stalk breaking force (SBF) gradually increased with increased nitrogen fertilizer application. Across the two years studied, compared with the N150 (Nf) treatment, the SBF of N250 treatments increased by $3.5-26.1 \%, 6.2-38.2 \%$, and $8.8-64.7 \%$ at the silking, maturity, and harvest stages, respectively. Under the N350 treatments, the SBF of the three periods increased by $24.2-45.4 \%, 28.1-58.6 \%$, and $38.5-78.8 \%$. Under the same application rate, the SBF gradually increases as the postponed nitrogen application increases. The SBF at maturity and harvest stages were lower than that at silking. In 2019, the SBF at maturity and harvest decreased more than that in 2018, caused by the positioning test in two years. 

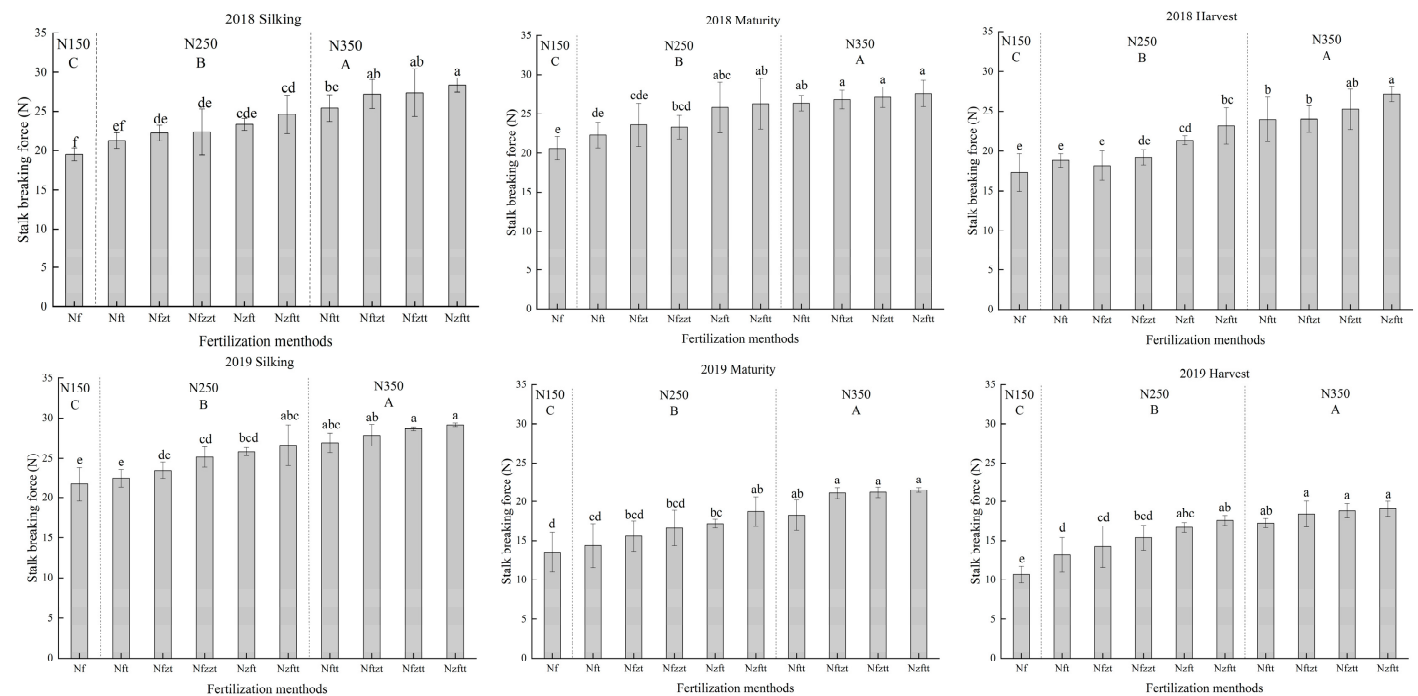

Figure 1. Effect of fertilization methods on cellulose and lignin contents of the third elongation internode at harvest stage under different nitrogen application rates. N150, N250, and N350 refer to the nitrogen application rate were 150,250 , and $350 \mathrm{~kg} \mathrm{ha}^{-1}$, respectively. " $\mathrm{z}$ " refers to the nitrogen application rate being zero, " $\mathrm{f}$ " refers to the nitrogen application rate being $150 \mathrm{~kg} \mathrm{ha}^{-1}$, " $\mathrm{t}$ " refers to the nitrogen application rate being $100 \mathrm{~kg} \mathrm{ha}^{-1}$, e.g., Nf refers to nitrogen application rate being $150 \mathrm{~kg} \mathrm{ha}^{-1}$ at sowing stage; Nfzt refers to nitrogen application rate being 150, 0, and $100 \mathrm{~kg} \mathrm{ha}^{-1}$ at sowing, 6-leaf, and 12-leaf stages, respectively; Nzftt refers to the nitrogen application rate being 0, 150, 100, and $100 \mathrm{~kg} \mathrm{ha}^{-1}$ at sowing, 6-leaf, 12-leaf, and silking stages, respectively. Capital letters indicate a significant difference at the $p<0.05$ level under different nitrogen application rates. Lowercase letters indicate a significant difference at the $p<0.05$ under all treatments.

\subsection{Plant Morphology}

The plant height, ear height, ear ratio, center of gravity height, and stalk diameter of maize plants increased with increasing nitrogen application, while the gravity ratio exhibited no significant difference across the two years study (Table 3). The postponed nitrogen application had a significant effect on plant height, ear height, ear ratio, and stalk diameter, but had little effect on the center of gravity height and gravity ratio. There was no significant difference in center of gravity height between the years. The plant height, ear height, ear ratio, center of gravity height, gravity ratio, and stalk diameter of maize plants was also influenced by nitrogen application rate $\times$ fertilization method and growth season $\times$ nitrogen application rate $\times$ fertilization method interaction effects.

Table 3. Effect of the fertilization methods on the morphology of plant and basal internode under different nitrogen application rates.

\begin{tabular}{|c|c|c|c|c|c|c|c|c|}
\hline Year & $\begin{array}{c}\text { Nitrogen } \\
\text { Application } \\
\text { Rate }\end{array}$ & $\begin{array}{l}\text { Fertilization } \\
\text { Methods }\end{array}$ & $\begin{array}{l}\text { Plant } \\
\text { Height } \\
\text { (cm) }\end{array}$ & $\begin{array}{l}\text { Ear Height } \\
\text { (cm) }\end{array}$ & $\begin{array}{c}\text { Ear Ratio } \\
\text { (\%) }\end{array}$ & $\begin{array}{c}\text { Center of } \\
\text { Gravity } \\
\text { Height }(\mathrm{cm})\end{array}$ & $\begin{array}{l}\text { Gravity } \\
\text { Ratio }\end{array}$ & $\begin{array}{l}\text { Third Internode } \\
\text { Diameter (mm) }\end{array}$ \\
\hline \multirow{10}{*}{2018} & N150 & $\mathrm{Nf}$ & $266 \mathrm{f}$ & $93.8 \mathrm{f}$ & $35.3 \mathrm{~cd}$ & $84.0 \mathrm{~d}$ & $31.6 \mathrm{a}$ & $18.5 \mathrm{~d}$ \\
\hline & \multirow{5}{*}{ N250 } & $\mathrm{Nft}$ & $271.2 \mathrm{e}$ & $94.4 \mathrm{f}$ & $34.8 \mathrm{~d}$ & $85.8 \mathrm{~cd}$ & $31.6 \mathrm{a}$ & $18.7 \mathrm{~d}$ \\
\hline & & Nfzt & $272 \mathrm{e}$ & $95.5 \mathrm{ef}$ & $35.1 \mathrm{~d}$ & $87.0 \mathrm{bcd}$ & $32.0 \mathrm{a}$ & $19.2 \mathrm{cb}$ \\
\hline & & Nfzzt & 27de & 96.2 ef & $35.3 \mathrm{~cd}$ & $88.0 \mathrm{abc}$ & $32.3 \mathrm{a}$ & $19.6 \mathrm{bcd}$ \\
\hline & & $\mathrm{Nzft}$ & 274 cde & $98.4 \mathrm{de}$ & $35.9 \mathrm{~cd}$ & $88.5 \mathrm{abc}$ & $32.3 \mathrm{a}$ & $20.7 \mathrm{ab}$ \\
\hline & & $\mathrm{Nzftt}$ & $276.2 \mathrm{bcd}$ & $100.6 \mathrm{~cd}$ & $36.4 \mathrm{bcd}$ & $89.4 \mathrm{abc}$ & $32.4 \mathrm{a}$ & $19.9 \mathrm{abcd}$ \\
\hline & \multirow{4}{*}{ N350 } & $\mathrm{Nftt}$ & $276.8 \mathrm{abc}$ & $100.4 \mathrm{~cd}$ & $36.3 \mathrm{bcd}$ & $89.7 \mathrm{ab}$ & $32.4 \mathrm{a}$ & $20.9 \mathrm{ab}$ \\
\hline & & Nftzt & $277.8 \mathrm{abc}$ & $102.4 b c$ & $36.9 \mathrm{bc}$ & $90.2 \mathrm{ab}$ & $32.5 \mathrm{a}$ & $20.1 \mathrm{abc}$ \\
\hline & & Nfztt & $278.6 \mathrm{ab}$ & $105.6 \mathrm{~b}$ & $37.9 \mathrm{ab}$ & $90.4 \mathrm{ab}$ & $32.5 \mathrm{a}$ & $20.5 \mathrm{abc}$ \\
\hline & & Nzftt & $280.6 \mathrm{a}$ & $110.4 \mathrm{a}$ & $39.3 \mathrm{a}$ & $91.0 \mathrm{a}$ & $32.4 \mathrm{a}$ & $21.2 \mathrm{a}$ \\
\hline
\end{tabular}


Table 3. Cont.

\begin{tabular}{|c|c|c|c|c|c|c|c|c|}
\hline Year & $\begin{array}{c}\text { Nitrogen } \\
\text { Application } \\
\text { Rate }\end{array}$ & $\begin{array}{l}\text { Fertilization } \\
\text { Methods }\end{array}$ & $\begin{array}{c}\text { Plant } \\
\text { Height } \\
\text { (cm) }\end{array}$ & $\begin{array}{l}\text { Ear Height } \\
\text { (cm) }\end{array}$ & $\begin{array}{c}\text { Ear Ratio } \\
(\%)\end{array}$ & $\begin{array}{c}\text { Center of } \\
\text { Gravity } \\
\text { Height }(\mathrm{cm})\end{array}$ & $\begin{array}{l}\text { Gravity } \\
\text { Ratio }\end{array}$ & $\begin{array}{l}\text { Third Internode } \\
\text { Diameter (mm) }\end{array}$ \\
\hline \multirow{17}{*}{2019} & N150 & $\mathrm{Nf}$ & $254.7 \mathrm{e}$ & $87.3 \mathrm{e}$ & $34.3 c$ & $82.2 \mathrm{e}$ & $32.3 \mathrm{a}$ & $15.8 \mathrm{e}$ \\
\hline & \multirow{5}{*}{ N250 } & $\mathrm{Nft}$ & $259.0 \mathrm{~d}$ & $88.0 \mathrm{e}$ & $34.0 \mathrm{c}$ & 86 de & $33.2 \mathrm{a}$ & $16.1 \mathrm{de}$ \\
\hline & & Nfzt & $261.7 \mathrm{~d}$ & $90.2 \mathrm{e}$ & $34.5 \mathrm{bc}$ & 86.3 cde & $33.0 \mathrm{a}$ & $17.1 \mathrm{~cd}$ \\
\hline & & Nfzzt & $266.5 \mathrm{c}$ & $94.6 \mathrm{~d}$ & $35.5 \mathrm{abc}$ & $89.3 \mathrm{bcd}$ & $33.5 \mathrm{a}$ & $17.5 \mathrm{abc}$ \\
\hline & & $\mathrm{Nzft}$ & $268.7 \mathrm{c}$ & $96.8 \mathrm{~cd}$ & $36.0 \mathrm{ab}$ & 89 abcd & $33.1 \mathrm{a}$ & $18.4 \mathrm{ab}$ \\
\hline & & $\mathrm{Nzftt}$ & $268.3 c$ & $97.9 \mathrm{bcd}$ & $36.5 \mathrm{a}$ & $91.3 \mathrm{abcd}$ & $34.0 \mathrm{a}$ & $18.0 \mathrm{abc}$ \\
\hline & \multirow{4}{*}{ N350 } & $\mathrm{Nftt}$ & $270.0 \mathrm{bc}$ & $98.1 \mathrm{bcd}$ & $36.3 \mathrm{a}$ & 91.5 abcd & $33.9 \mathrm{a}$ & $18.6 \mathrm{a}$ \\
\hline & & Nftzt & $273.3 \mathrm{ab}$ & $100.3 \mathrm{abc}$ & $36.7 \mathrm{a}$ & $92.5 \mathrm{abc}$ & $33.8 \mathrm{a}$ & $18.0 \mathrm{abc}$ \\
\hline & & Nfztt & $276.5 \mathrm{a}$ & $102.2 \mathrm{ab}$ & $36.9 a$ & $95.2 \mathrm{ab}$ & $34.4 \mathrm{a}$ & $17.3 \mathrm{bc}$ \\
\hline & & $\mathrm{Nzftt}$ & $277.2 \mathrm{a}$ & $102.7 \mathrm{a}$ & $37.0 \mathrm{a}$ & $95.5 \mathrm{a}$ & $34.5 \mathrm{a}$ & $18.4 \mathrm{ab}$ \\
\hline & Year (Y) & & $* *$ & $* *$ & * & ns & $* *$ & $* *$ \\
\hline & $\mathrm{N}$ rate $(\mathrm{N})$ & & $* *$ & $* *$ & $* *$ & $* *$ & $* *$ & $* *$ \\
\hline & Method (M) & & $* *$ & $* *$ & $* *$ & ns & ns & $* *$ \\
\hline & $\mathrm{Y} \times \mathrm{N}$ & & $* *$ & $* *$ & $* *$ & $* *$ & $* *$ & $* *$ \\
\hline & $\mathrm{Y} \times \mathrm{M}$ & & ns & ns & ns & ns & ns & ns \\
\hline & $\mathrm{N} \times \mathrm{M}$ & & $* *$ & $* *$ & $* *$ & $* *$ & $* *$ & $* *$ \\
\hline & $\mathrm{Y} \times \mathrm{N} \times \mathrm{M}$ & & $* *$ & $* *$ & $* *$ & $* *$ & $* *$ & $* *$ \\
\hline
\end{tabular}

Note: N150, N250, and N350 refer to the nitrogen application rate being 150, 250 and $350 \mathrm{~kg} \mathrm{ha}^{-1}$, respectively. " $\mathrm{z}$ " refers to the nitrogen application rate being zero, " $\mathrm{f}$ " refers to the nitrogen application rate being $150 \mathrm{~kg} \mathrm{ha}^{-1}$ " $\mathrm{t}$ " refers to the nitrogen application rate being $100 \mathrm{~kg} \mathrm{ha}^{-1}$, e.g., $\mathrm{Nf}$ refers to nitrogen application rate being $150 \mathrm{~kg} \mathrm{ha}^{-1}$ at sowing stage; Nfzt refers to nitrogen application rate being 150, 0, and $100 \mathrm{~kg} \mathrm{ha}^{-1}$ at sowing, 6-leaf, and 12-leaf stages, respectively; Nzftt refers to the nitrogen application rate being 0, 150, 100, and $100 \mathrm{~kg} \mathrm{ha}^{-1}$ at sowing, 6-leaf, 12-leaf, and silking stages, respectively. Different letters indicate significant differences at the $p<0.05$ level under different nitrogen application rates and fertilization methods in the same year. ${ }^{*}$ and ${ }^{* *}$ represent significant levels of $p=0.05$ and $p=0.01$, respectively; ns represents no significant difference.

\subsection{Rind Penetration Strength of the Basal Internode}

The nitrogen rate and postponed treatments significantly affected the rind penetration strength (RPS) of the third elongation internode at the base of maize plants (Figure 2). As nitrogen application rates increased, the RPS also increased gradually. Across the two study years, compared with the N150, the RPS of the N250 treatment increased by 1.8-18.3\%, $2.4-21.4 \%$, and 3.3-24.3\%, respectively, at the silking, maturity, and harvest stages. The RPS of the N350 treatment increased by $8.7-30.7 \%, 10.1-37.7 \%$, and $26.8-43.8 \%$ in the three growth periods, respectively. Under the same nitrogen application rate, the RPS gradually increased as the postponed nitrogen application increased.

\subsection{DWUL and Carbohydrates in the Basal Internode}

The nitrogen rate and postponed treatments significantly affected the dry weight per unit length (DWUL) of the third internode at harvest (Figure 3). As the nitrogen application rate increased, the DWUL increased gradually. Across the two years studied, compared with N150, the average DWUL of the N250 treatments increased by $20.9 \%$, and the average DWUL of the N350 treatments increased by $45.1 \%$. Under the same nitrogen application rate, as the nitrogen postponed nitrogen application increased, the DWUL also gradually increased.

Further analysis showed that the cellulose and lignin contents of internodes treated with N250 and N350 increased significantly compared with N150 (Figure 4). Across the two-year study, the average cellulose content increased by $28.0 \%$ in the $\mathrm{N} 250$ treatment and $38.8 \%$ in the N350 treatment. The average lignin content increased by $37.4 \%$ in the N250 treatment and $38.9 \%$ in the N350 treatment. Under the same nitrogen application rate, as the postponed nitrogen application increased, the cellulose and lignin content of the third internode also showed increasing trends. 

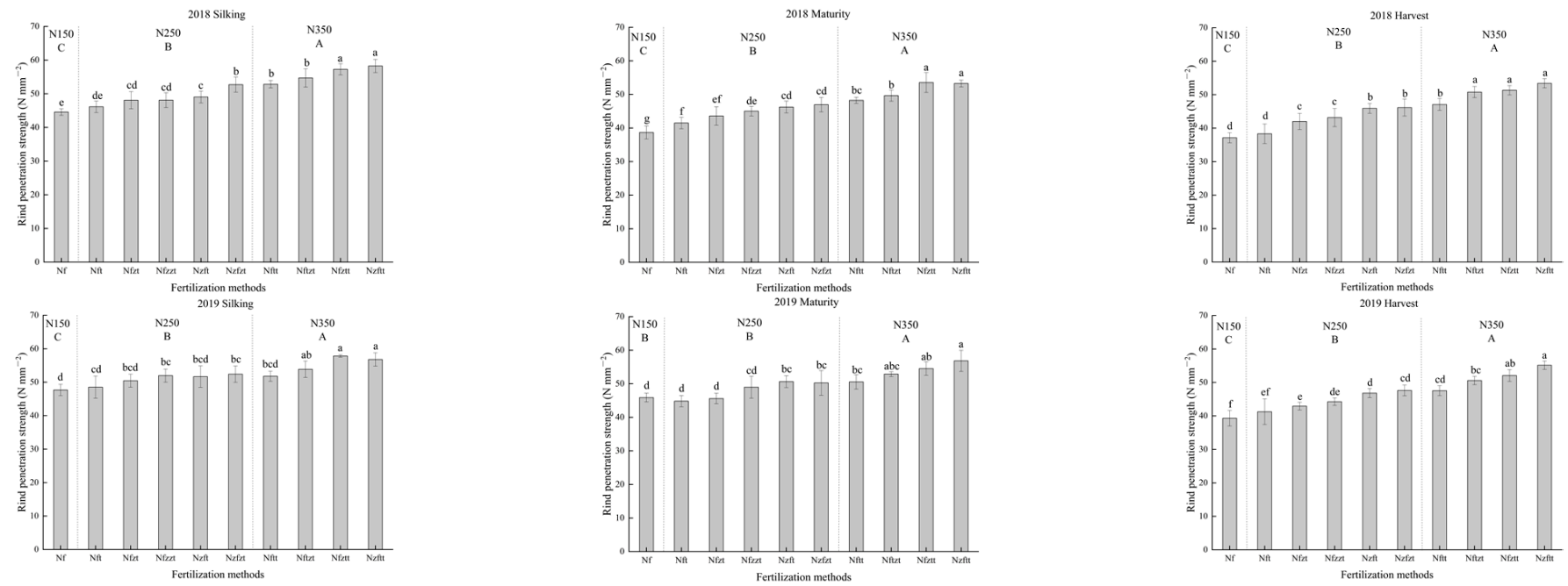

Figure 2. Effect of fertilization methods on rind penetration strength of the third elongation internode at silking stage, maturity stage, and harvest stage under different nitrogen application rates. N150, N250, and N350 refer to the nitrogen application rate being 150, 250, and $350 \mathrm{~kg} \mathrm{ha}^{-1}$, respectively. " $\mathrm{z}$ " refers to the nitrogen application rate being zero, " $\mathrm{f}$ " refers to the nitrogen application rate being $150 \mathrm{~kg} \mathrm{ha}^{-1}$, " $\mathrm{t}$ " refers to the nitrogen application rate being $100 \mathrm{~kg} \mathrm{ha}^{-1}$, e.g., $\mathrm{Nf}$ refers to nitrogen application rate being $150 \mathrm{~kg} \mathrm{ha}^{-1}$ at sowing stage; Nfzt refers to nitrogen application rate being 150,0 , and $100 \mathrm{~kg} \mathrm{ha}^{-1}$ at sowing, 6-leaf, and 12-leaf stages, respectively; Nzftt refers to the nitrogen application rate being $0,150,100$, and $100 \mathrm{~kg} \mathrm{ha}^{-1}$ at sowing, 6-leaf, 12-leaf, and silking stages, respectively. Capital letters indicate a significant difference at the $p<0.05$ level under different nitrogen application rates. Lowercase letters indicate a significant difference at the $p<0.05$ under all treatments.

2018

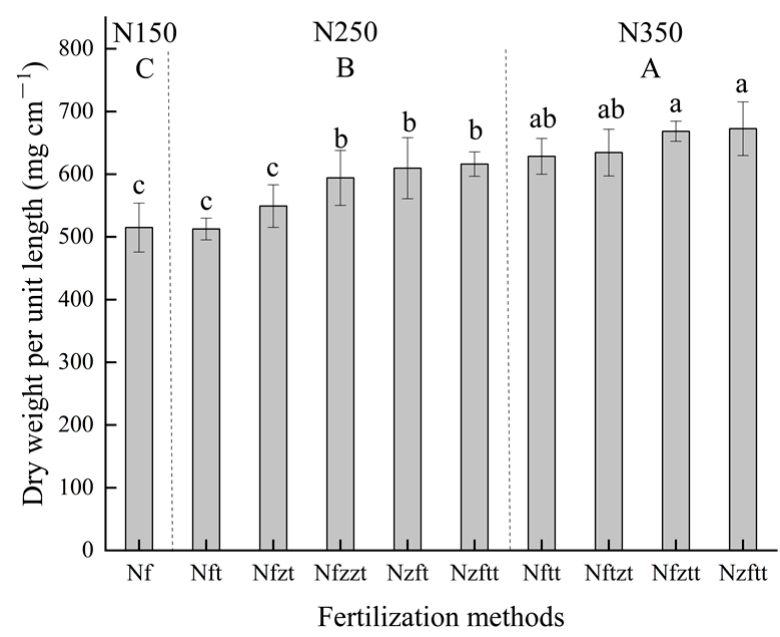

2019

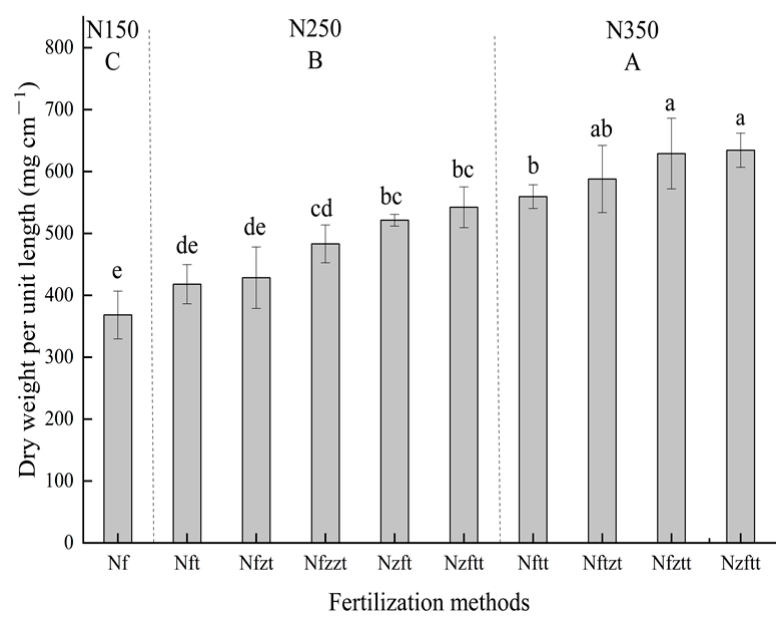

Figure 3. Effect of fertilization methods on dry weight per unit length of the third elongation internode at harvest stage under different nitrogen application rates. N150, N250, and N350 refer to the nitrogen application rate being 150,250 , and $350 \mathrm{~kg} \mathrm{ha}^{-1}$, respectively. " $\mathrm{z}$ " refers to the nitrogen application rate being zero, " $\mathrm{f}$ " refers to the nitrogen application rate being $150 \mathrm{~kg} \mathrm{ha}^{-1}$, " $t$ " refers to the nitrogen application rate being $100 \mathrm{~kg} \mathrm{ha}^{-1}$, e.g., Nf refers to nitrogen application rate being $150 \mathrm{~kg} \mathrm{ha}^{-1}$ at sowing stage; Nfzt refers to nitrogen application rate being 150, 0 , and $100 \mathrm{~kg} \mathrm{ha}^{-1}$ at sowing, 6-leaf, and 12-leaf stages, respectively; Nzftt refers to the nitrogen application rate being $0,150,100$, and $100 \mathrm{~kg} \mathrm{ha}^{-1}$ at sowing, 6-leaf, 12-leaf, and silking stages, respectively. Capital letters indicate a significant difference at the $p<0.05$ level under different nitrogen application rates. Lowercase letters indicate a significant difference at the $p<0.05$ under all treatments. 

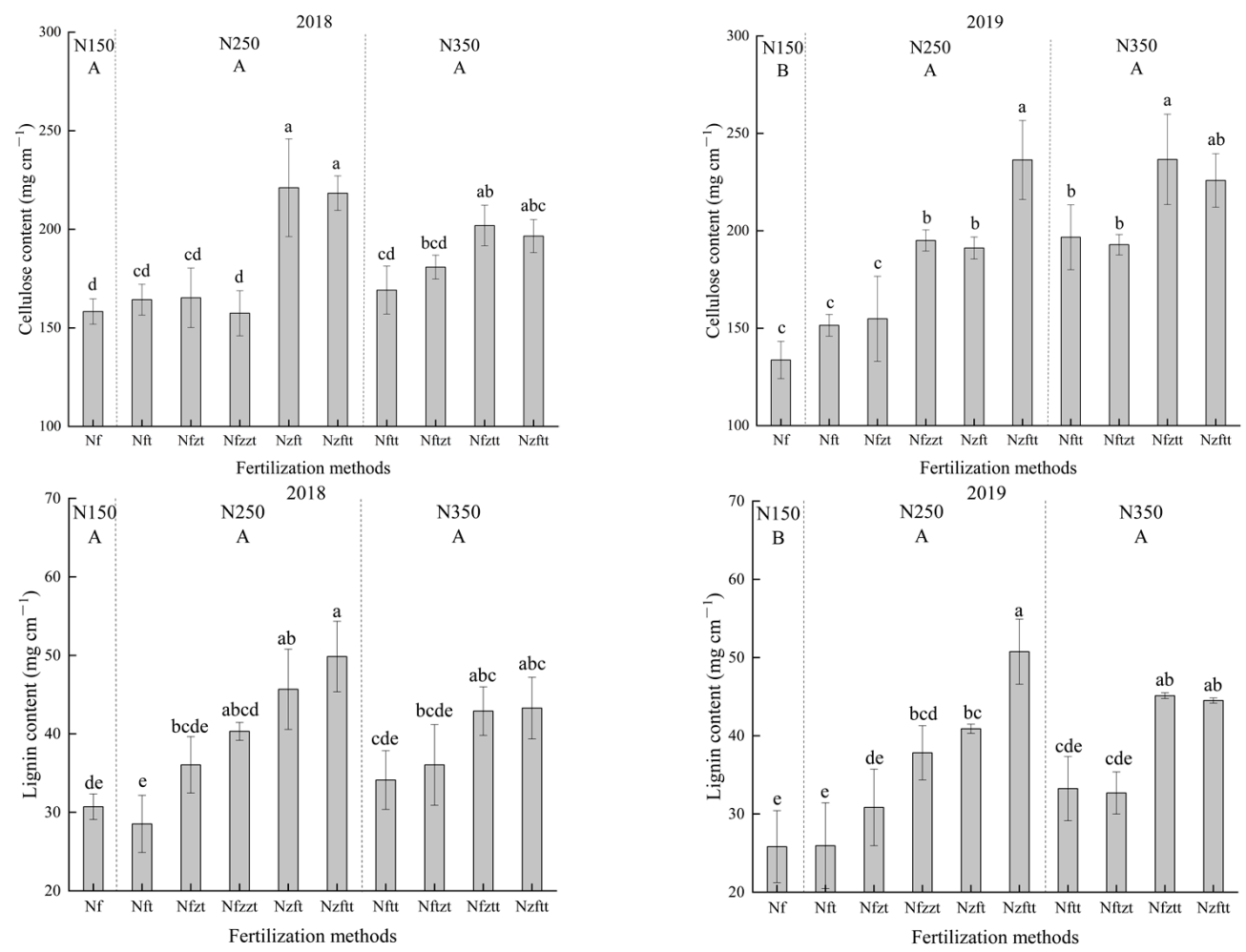

Figure 4. Effect of fertilization methods on cellulose and lignin contents of the third elongation internode at harvest stage under different nitrogen application rates. N150, N250, and N350 refer to the nitrogen application rate being 150,250 , and $350 \mathrm{~kg} \mathrm{ha}^{-1}$, respectively. " $\mathrm{z}$ " refers to the nitrogen application rate being zero, " $\mathrm{f}$ " refers to the nitrogen application rate being $150 \mathrm{~kg} \mathrm{ha}^{-1}$, " $\mathrm{t}$ " refers to the nitrogen application rate being $100 \mathrm{~kg} \mathrm{ha}^{-1}$, e.g., Nf refers to nitrogen application rate being $150 \mathrm{~kg} \mathrm{ha}^{-1}$ at sowing stage; Nfzt refers to nitrogen application rate being 150, 0 , and $100 \mathrm{~kg} \mathrm{ha}^{-1}$ at sowing, 6-leaf, and 12-leaf stages, respectively; Nzftt refers to the nitrogen application rate being $0,150,100$, and $100 \mathrm{~kg} \mathrm{ha}^{-1}$ at sowing, 6-leaf, 12-leaf and silking stages, respectively. Capital letters indicate a significant difference at the $p<0.05$ level under different nitrogen application rates. Lowercase letters indicate a significant difference at the $p<0.05$ under all treatments.

\subsection{Total N Content of the Basal Internode}

The nitrogen rate and postponed treatments significantly affected the total $\mathrm{N}$ content of the third internode at harvest (Figure 5). As the nitrogen application rate increased, the total $\mathrm{N}$ content increased gradually. Across the two years studied, compared with N150, the average total $\mathrm{N}$ content increased by $42.3 \%$ in the N250 treatment and increased by $71.3 \%$ in the N350 treatment. Under the same nitrogen application rate, the total nitrogen content in the third internode increased alongside the postponed nitrogen application.

\subsection{Correlation Analysis of the Lodging Resistance Index}

At the harvest stage of maize, the stalk breaking force was significantly positively correlated with plant height, ear height, ear position coefficient, stalk diameter, rind penetration strength, dry weight per unit length, cellulose content, lignin content, and total nitrogen content of the third internode (Table 4 ).

There was a positive linear correlation between rind penetration strength (RPS) and cellulose and lignin contents of the third internode (Figure 6). For each $1 \mathrm{mg} \mathrm{cm}^{-1}$ increase of cellulose, the RPS under the N250 and N350 treatments increased by $0.074 \mathrm{~N} \mathrm{~mm}^{-2}$ and $0.0815 \mathrm{~N} \mathrm{~mm}^{-2}$, respectively. For each $1 \mathrm{mg} \mathrm{cm}^{-1}$ increase of lignin, the RPS under the $\mathrm{N} 250$ and $\mathrm{N} 350$ treatments increased by $0.2899 \mathrm{~N} \mathrm{~mm}^{-2}$ and $0.4025 \mathrm{~N} \mathrm{~mm}^{-2}$, respectively. This showed that under high fertilization levels, changes in cellulose and lignin content have a high degree of influence on the stalk strength. 

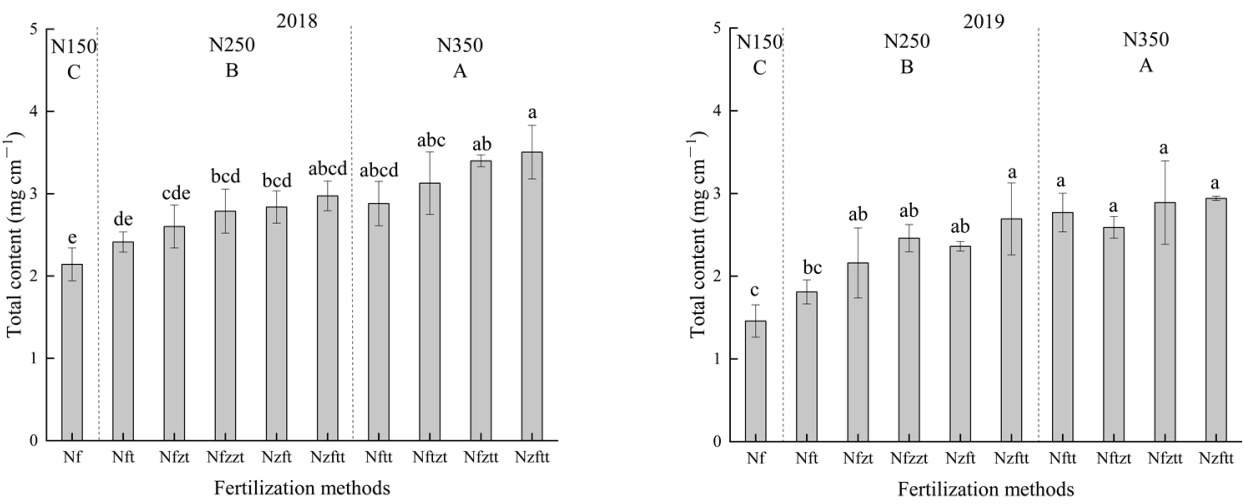

Figure 5. Effect of fertilization methods on $\mathrm{N}$ content of the third elongation internode at harvest stage under different nitrogen application rates. N150, N250, and N350 refer to the nitrogen application rate being 150,250 , and $350 \mathrm{~kg} \mathrm{ha}^{-1}$, respectively. " $\mathrm{z}$ " refers to the nitrogen application rate being zero, " $\mathrm{f}$ " refers to the nitrogen application rate being $150 \mathrm{~kg} \mathrm{ha}^{-1}$, " $\mathrm{t}$ " refers to the nitrogen application rate being $100 \mathrm{~kg} \mathrm{ha}^{-1}$, e.g., Nf refers to nitrogen application rate being $150 \mathrm{~kg} \mathrm{ha}^{-1}$ at sowing stage; Nfzt refers to nitrogen application rate being 150, 0, and $100 \mathrm{~kg} \mathrm{ha}^{-1}$ at sowing, 6-leaf, and 12-leaf stages, respectively; Nzftt refers to the nitrogen application rate being $0,150,100$, and $100 \mathrm{~kg} \mathrm{ha}^{-1}$ at sowing, 6-leaf, 12-leaf, and silking stages, respectively. Capital letters indicate a significant difference at the $p<0.05$ level under different nitrogen application rates. Lowercase letters indicate a significant difference at the $p<0.05$ under all treatments.

Table 4. Correlation analysis between stalk breaking force and plant morphology, stalk mechanical strength, and material content at harvest.

\begin{tabular}{cc}
\hline & Stalk Breaking Force \\
\hline Plant height & $0.928^{* *}$ \\
Ear height & $0.901^{* *}$ \\
Ear coefficient & $0.823^{* *}$ \\
Diameter & $0.936^{* *}$ \\
Rind penetration strength & $0.624^{* *}$ \\
Dry weight per unit length & $0.927^{* *}$ \\
Cellulose content & $0.530^{*}$ \\
Lignin content & $0.621^{* *}$ \\
Total N content & $0.915^{* *}$
\end{tabular}
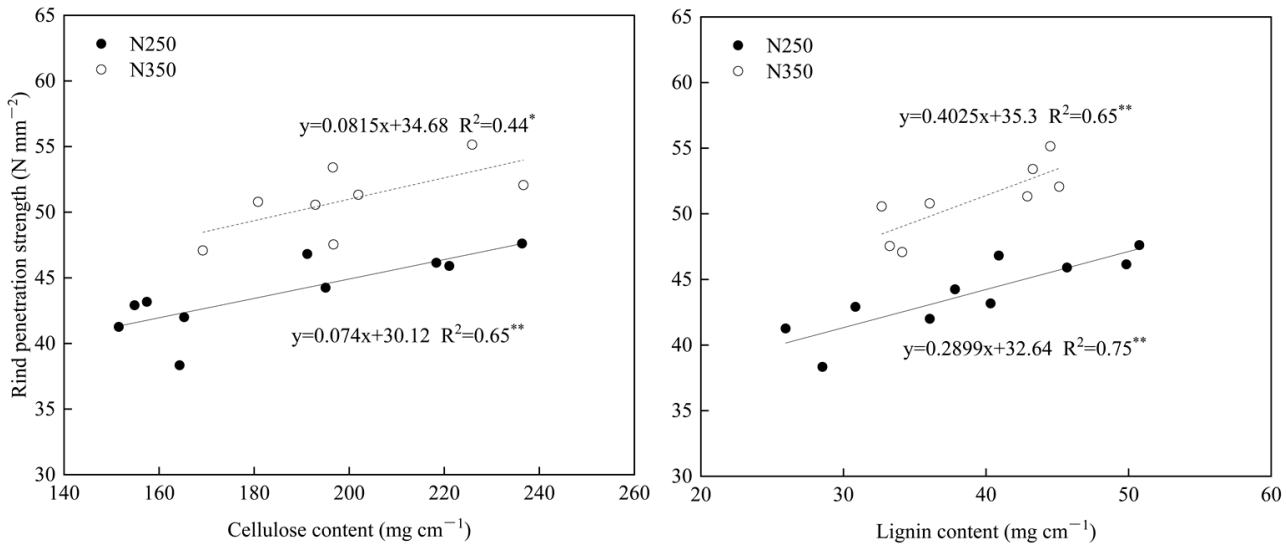

Figure 6. Relationship between the rind penetration strength, cellulose, and lignin contents of the third elongation internode under different nitrogen application rates. N250 and N350 refer to the nitrogen application rate being 250 and $350 \mathrm{~kg} \mathrm{ha}^{-1}$, respectively. * and ${ }^{* *}$ represent significant correlations between the levels of $p=0.05$ and $p=0.01$, respectively. 


\subsection{Grain Yield}

The nitrogen rate and postponed treatments significantly affected grain yield at harvest (Figure 7). Nitrogen application rate and fertilization period had no significant effects on kernel weight. During the two years studied, the average grain yield and kernel number increased at first, then decreased with increasing amount of nitrogen applied.
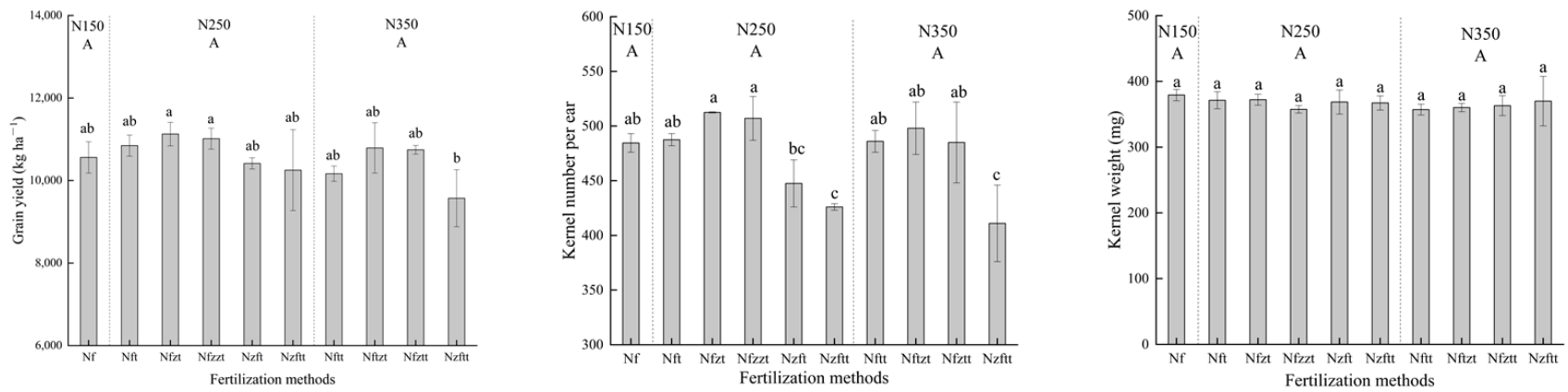

Figure 7. Effects of fertilization methods on maize yield, kernel number per ear, and kernel weight under different nitrogen application rates. N150, N250, and N350 refer to the nitrogen application rate being 150,250 , and $350 \mathrm{~kg} \mathrm{ha}^{-1}$, respectively. " $\mathrm{z}$ " refers to the nitrogen application rate being zero, " $\mathrm{f}$ " refers to the nitrogen application rate being $150 \mathrm{~kg} \mathrm{ha}^{-1}$, " $\mathrm{t}$ " refers to the nitrogen application rate being $100 \mathrm{~kg} \mathrm{ha}^{-1}$, e.g., Nf refers to nitrogen application rate being $150 \mathrm{~kg} \mathrm{ha}^{-1}$ at sowing stage; Nfzt refers to nitrogen application rate being 150,0 , and $100 \mathrm{~kg} \mathrm{ha}^{-1}$ at sowing, 6-leaf, and 12-leaf stages, respectively; Nzftt refers to the nitrogen application rate being $0,150,100$, and $100 \mathrm{~kg} \mathrm{ha}^{-1}$ at sowing, 6-leaf, 12-leaf, and silking stages, respectively. The data were averaged over 2018 and 2019. Capital letters indicate a significant difference at the $p<0.05$ level under different nitrogen application rates. Lowercase letters indicate a significant difference at the $p<0.05$ under all treatments.

\subsection{Dry Matter and Leaf Area Index}

The nitrogen rate and postponed treatments had significant effects on the dry matter accumulation of maize plants (Figure 8). The dry weight of maize gradually increased with increasing nitrogen application rate. At the silking stage, compared with N150, the average dry weight of the N250 and N350 treatments increased by $26.8 \%$ and $35.1 \%$, respectively. At maturity, the average dry weight increased by $12.0 \%$ and $16.8 \%$, respectively.
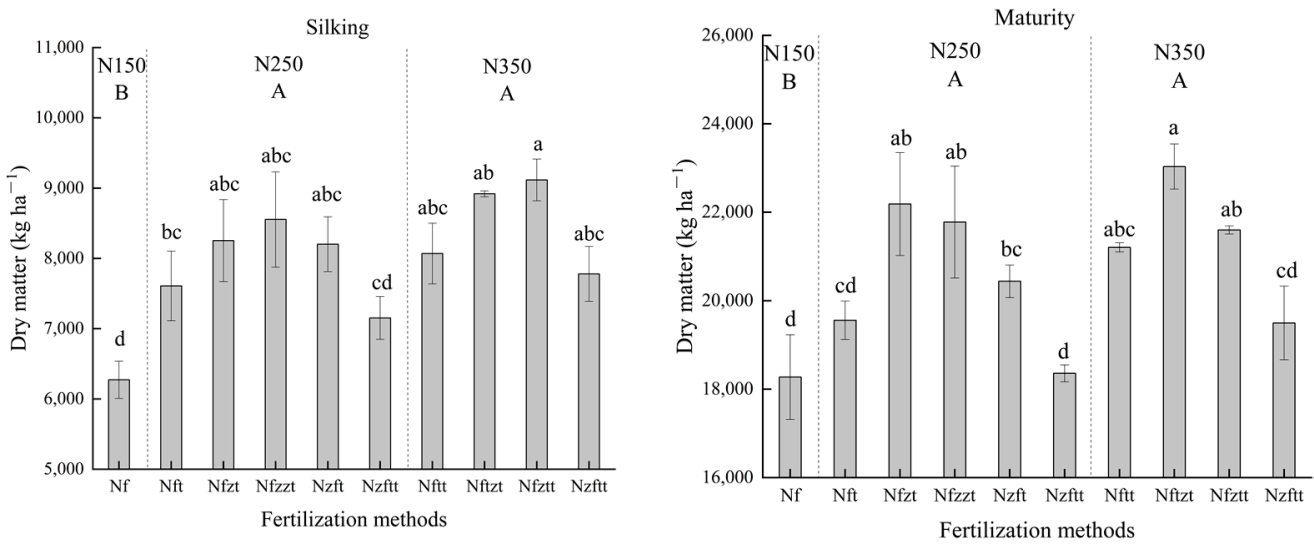

Figure 8. Effects of fertilization methods on dry matter at silking and maturity stages under different nitrogen application rates. N150, N250, and N350 refer to the nitrogen application rate being 150, 250 , and $350 \mathrm{~kg} \mathrm{ha}^{-1}$, respectively. " $\mathrm{z}$ " refers to the nitrogen application rate being zero, " $\mathrm{f}$ " refers to the nitrogen application rate being $150 \mathrm{~kg} \mathrm{ha}^{-1}$, " $\mathrm{t}$ " refers to the nitrogen application rate being $100 \mathrm{~kg} \mathrm{ha}^{-1}$, e.g., Nf refers to nitrogen application rate being $150 \mathrm{~kg} \mathrm{ha}^{-1}$ at sowing stage; e.g., $\mathrm{Nf}$ refers to nitrogen application rate being $150 \mathrm{~kg} \mathrm{ha}^{-1}$ at sowing stage; Nfzt refers to nitrogen application rate being 150, 0, and $100 \mathrm{~kg} \mathrm{ha}^{-1}$ at sowing, 6-leaf, and 12-leaf stages, respectively; Nzftt 
refers to the nitrogen application rate being 0,150, 100, and $100 \mathrm{~kg} \mathrm{ha}^{-1}$ at sowing, 6-leaf, 12-leaf, and silking stages, respectively. The data were averaged over 2018 and 2019. Capital letters indicate a significant difference at the $p<0.05$ level under different nitrogen application rates. Lowercase letters indicate a significant difference at the $p<0.05$ under all treatments.

As the nitrogen application rate increased, the leaf area index (LAI) also gradually increased (Figure 9). At the silking stage, the postponed nitrogen application had no significant effect on the LAI. At the maturity stage, under the N350 treatment, the LAI significantly increased as the postponed nitrogen application increased.
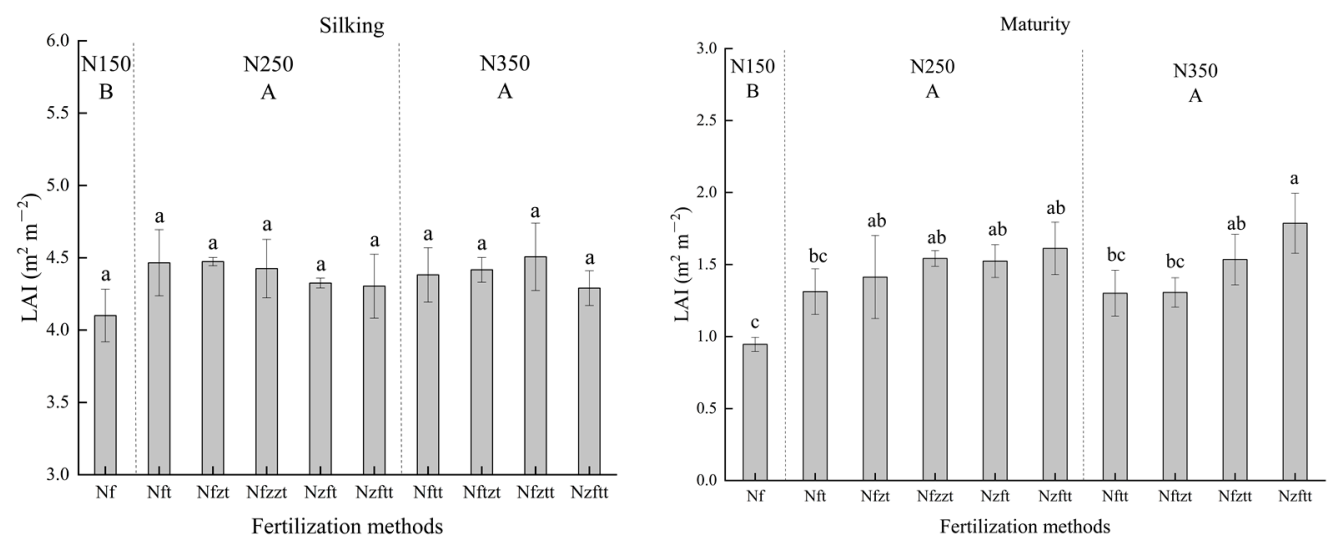

Figure 9. Effects of fertilization methods on leaf area index (LAI) at silking and maturity stages under different nitrogen application rates. N150, N250, and N350 refer to the nitrogen application rate being 150,250 , and $350 \mathrm{~kg} \mathrm{ha}^{-1}$, respectively. " $\mathrm{z}$ " refers to the nitrogen application rate being zero, " $\mathrm{f}$ " refers to the nitrogen application rate being $150 \mathrm{~kg} \mathrm{ha}^{-1}$, " $\mathrm{t}$ " refers to the nitrogen application rate being $100 \mathrm{~kg} \mathrm{ha}^{-1}$, e.g., Nf refers to nitrogen application rate being $150 \mathrm{~kg} \mathrm{ha}^{-1}$ at sowing stage; Nfzt refers to nitrogen application rate being 150,0 , and $100 \mathrm{~kg} \mathrm{ha}^{-1}$ at sowing, 6-leaf, and 12-leaf stages, respectively; Nzftt refers to the nitrogen application rate being $0,150,100$, and $100 \mathrm{~kg} \mathrm{ha}^{-1}$ at sowing, 6-leaf, 12-leaf, and silking stages, respectively. The data were averaged over 2018 and 2019. Capital letters indicate a significant difference at the $p<0.05$ level under different nitrogen application rates. Lowercase letters indicate a significant difference at the $p<0.05$ under all treatments.

\section{Discussion}

Maize lodging is affected by plant morphology, stalk dry matter accumulation, and mechanical strength. Plants with long basal internodes have a higher ear position coefficient and center of gravity, which increases the risk of stalk lodging. Both the DWUL and RPS of the basal internodes are significantly positively correlated with stalk lodging resistance [36]. At the six-leaf stage of maize, the basal internodes enter a rapid growth period. During this period, if a large amount of nitrogen fertilizer is applied, the basal internodes will elongate rapidly, and material filling and stalk strength cannot occur rapidly enough, resulting in reduced lodging resistance of the basal stalk [37]. In this study, the stalk breaking force (SBF) was used to evaluate lodging resistance as a comprehensive indicator. As the nitrogen application rate increased, the SBF increased. Further analysis showed that as the nitrogen application rate increased, so did the plant height, ear height, ear ratio, height of the center of gravity, and the gravity ratio, all of which are not conducive to lodging resistance of maize. However, the internode diameter, DWUL, and mechanical strength increased with increasing nitrogen application rate, conducive to lodging resistance. Shi et al. [24] showed that under high density planting conditions, increased nitrogen application improved the stalk diameter, puncture strength, and bending performance and reduced the lodging rate of maize. Liu Ming et al. [23] determined that as nitrogen application rates increased the stalk breaking strength increased at first and then decreased, in spring maize. At an application rate of $225 \mathrm{~kg} \mathrm{ha}^{-1}$, the highest stalk breaking strength and lowest lodging rate occur. Therefore, the stalk lodging resistance of maize was improved by increased 
nitrogen application rate by increasing the internode diameter, material accumulation, and mechanical strength.

During the vegetative growth period of maize, the basal internodes first undergo rapid thickening and elongation, followed by rapid accumulation of dry matter and synthesis of structural, chemical components, ultimately resulting in stalk strength [38]. Bian et al. showed that nitrogen application at the V12 stage could significantly promote increased stalk diameter and reduce the internode length to diameter ratio [22]. In contrast to traditional irrigation and fertilization methods, the present study employed integrated water and fertilizer drip irrigation and the postponed nitrogen application to investigate the effects of nitrogen fertilizer management on stalk lodging. In this way, adverse developmental outcomes in maize resulting from excessive nitrogen fertilizer caused by early, long term, and improper fertilization time are avoided. The postponed nitrogen application treatment proved beneficial for increasing cellulose, lignin, and total nitrogen content of the basal internode during the stalk development period. In addition, under the same rate as nitrogen applications, the postponed nitrogen application treatments improve the lodging resistance of maize stalks at the maturity stage. A possible reason for this is that the postponed nitrogen application promotes the accumulation of dry matter after maize flowering, improve the accumulation of stalk dry matter and mechanical strength, thereby enhancing the lodging resistance of stalks [39]. Therefore, under the same application rate, postponed nitrogen application is a useful strategy to improve stalk lodging resistance.

Carbohydrates in maize stalks are the material basis for the formation of mechanical strength [28]. Studies have shown that cellulose content in the internodes of the stalk under the ear contributes $85 \%$ to the strength of the maize stalk [40]. In the late stage of maize growth, the content of stored stalk materials was directly related to the compressive strength, and varieties with high stalk dry matter accumulation and lignin content showed greater lodging resistance [41]. Decreases in dry matter and moisture content of maize stalks caused by natural senescence of the plant after physiological maturity was the main reason for the decreased mechanical strength of the stalk and increased rate of stalk breaking [28]. In this study, the stalk lodging resistance at the harvest stage increased as the nitrogen application rate increased. Furthermore, the postponed nitrogen application treatment significantly improved stalk lodging resistance at harvest and had a greater influence on lodging resistance at the harvest stage than that at the silking and maturity stages. The main reason for this was that the postponed nitrogen application treatment promoted the absorption and utilization of nitrogen during the late growth stage of maize, which maintained a high green leaf area index, thus slowing the senescence rate, and improving the stalk mechanical strength and lodging resistance.

Stalk morphology, development, material accumulation, and mechanical strength formation occur during the vegetative growth period of maize [38]. During the middle and late grain filling stages, the filling rate is slow if the leaves do not have obvious yellowing and premature senescence at this time; compounds produced by photosynthesis will be stored in stalks, increasing the carbohydrate contents of the stalks. If the leaves are yellowed prematurely or even die and the activity of the stalks is reduced, disease resistance will also decrease due to respiration of the stalks. Consumption and decomposition of carbohydrates by pathogens causes the carbohydrate contents in stalks to decrease [27,42]. In this study, the integrated water and fertilizer drip irrigation method was used to accurately apply nitrogen fertilizer at specific growth stages. The postponed nitrogen application treatments increased mechanical strength before physiological maturity, thereby laying a foundation for and improving lodging resistance of stalks during the harvest period.

Summer maize achieves peak nutrient absorption during the 6-12 leaf and silking stages [43]. Basic one-time application of nitrogen fertilizer causes excessive nitrogen accumulation in the early stage of maize growth, inhibits nitrogen absorption and transport in the later growth stage, is not conducive to grain filling, and ultimately leads to reduced yields [44]. Some studies have shown that increasing fertilization frequency and fertilizer backward shift can improve maize LAI, delay leaf senescence, and increase maize dry 
matter accumulation [45]. In this study, the dry matter and yield of one-time fertilization treatment were significantly lower than those of other treatments. Maize yields will be higher if the postponed date is delayed. This showed that the postponed nitrogen application treatments at the V12 stage can meet the demand of maize growth. In addition, unreasonable postponed nitrogen application will lead to lack of nitrogen in the vegetative growth period, affecting maize ear development and decreasing the kernel number per ear, thus reducing yield. Therefore, the reasonable postponed nitrogen applications are conducive to obtaining a high grain yield and improving the stalk lodging resistance of summer maize.

\section{Conclusions}

Improving the lodging resistance of maize stalks during the early growth stage and building a high-quality population can delay stalk senescence and improve stalk quality in later growth stages. Under integrated water and fertilizer drip irrigation conditions, increasing nitrogen fertilizer and postponed nitrogen application can significantly improve the stalk lodging resistance. Based on the summer maize grain yield and stalk lodging resistance, under N250 treatment, base fertilizer combined with topdressing at 12-leaf and silking stages was beneficial to the growth of summer maize.

Author Contributions: Conceptualization, J.Z., J.X. and S.L.; methodology, J.Z., J.X., G.Z., Y.Z. and S.L.; investigation, J.Z., J.X. and M.T.; data analysis, J.Z., J.X., G.Z., R.X., B.M., P.H., K.W. and S.L.; writing-original draft preparation, J.Z. and J.X.; writing-review and editing, J.Z., J.X., G.Z., Y.Z., R.X., B.M., P.H., K.W. and S.L.; supervision, J.X. and S.L.; project administration, K.W. All authors have read and agreed to the published version of the manuscript.

Funding: This work was supported by the Agricultural Science and Technology Innovation Program (CAAS-ZDRW202004), Basic Scientific Research Fund of Chinese Academy of Agricultural Sciences (S2021ZD05), China Agriculture Research System of MOF and MARA.

Informed Consent Statement: Not applicable.

Data Availability Statement: Not applicable.

Acknowledgments: Not applicable.

Conflicts of Interest: The authors declare no conflict of interest.

\section{References}

1. Li, S.K.; Zhao, J.R.; Dong, S.T.; Zhao, M.; Li, C.H.; Cui, Y.H.; Liu, Y.H.; Gao, J.L.; Xue, J.Q.; Wang, L.C.; et al. Advances and Prospects of Maize Cultivation in China. Sci. Agric. Sin. 2017, 50, 1941-1959.

2. Erisman, J.W.; Sutton, M.A.; Galloway, J.; Klimont, Z.; Winiwarter, W. How a century of ammonia synthesis changes the world. Nat. Geosci. 2008, 1, 636-639. [CrossRef]

3. Ciampitti, I.A.; Vyn, T.J. A comprehensive study of plant density consequences on nitrogen uptake dynamics of maize plants from vegetative to reproductive stage. Field Crops Res. 2011, 121, 2-18. [CrossRef]

4. Afreh, D.; Zhang, J.; Guan, D.H.; Liu, K.L.; Song, Z.W.; Zheng, C.Y.; Deng, A.X.; Feng, X.M.; Zhang, X.; Wu, Y. Long-term fertilization on nitrogen use efficiency and greenhouse gas emissions in a double maize cropping system in subtropical China. Soil Tillage Res. 2018, 180, 259-267. [CrossRef]

5. Zhang, G.Q.; Shen, D.P.; Xie, R.Z.; Ming, B.; Hou, P.; Xue, J.; Li, R.F.; Chen, J.L.; Wang, K.R.; Li, S.K. Optimizing planting density to improve nitrogen use of super high-yield maize. Agron. J. 2020, 112, 4147-4158. [CrossRef]

6. Wang, Q.Y.; Hu, C.H.; Dong, S.T.; Gao, R.Z. Study on the changes of leaf age, chloroplast ultrastructure and photosynthetic performance in Maize. J. Maize Sci. 1992, 00, 36-39. [CrossRef]

7. Liu, G.J.; Kong, J.X.; Su, S.B. Study progress on maize nitrogen metabolism. J. Maize Sci. 2009, 17, $135-138$.

8. Kim, S.-H.; Sicher, R.C.; Bae, H.; Gitz, D.C.; Baker, J.T.; Timlin, D.J.; Reddy, V.R. Canopy photosynthesis, evapotranspiration, leaf nitrogen, and transcription profiles of maize in response to $\mathrm{CO}_{2}$ enrichment. Glob. Change Biol. 2006, 12, 588-600. [CrossRef]

9. Wang, Y.L.; Li, C.H.; He, P.; Jin, J.Y.; Han, Y.L.; Zhang, X.; Tan, J.F. Nutrient restrictive factors and accumulation of super-high-yield summer maize. Plant Nutr. Fert. Sci. 2010, 16, 559-566.

10. Wang, Y.L.; Li, C.H.; Tan, J.F.; Zhang, X.; Liu, T.X. Effect of postponing N application on yield, nitrogen absorpation and utilization in super-high-yield summer maize. Acta Agron. Sin. 2011, 37, 339-347. [CrossRef]

11. Hou, Y.P.; Yang, J.; Yin, C.X.; Qin, Y.B.; Li, Q.; Yu, L.; Kong, L.L.; Liu, Z.Q. Effect of postponing nitrogen application on the yield, nitrogen absorption and utilization and soil nitrogen supply in spring maize. J. Maize Sci. 2019, 27, 146-154. 
12. Gao, X.X.; Zhang, H.F.; Ma, W.Q.; Wei, J. Effects of nitrogen application rates on yield and nitrogen utilization of summer maize. J. Maize Sci. 2014, 22, 121-126.

13. Yang, D.G.; Niu, H.Y.; Zhang, H.X.; Wu, G.X. Effects of nitrogen stress and Non-stress on yield and quality traits of spring maize J. Maize Sci. 2008, 4, 55-57.

14. Tilman, D.; Cassman, K.G.; Matson, P.A.; Naylor, R.; Polasky, S. Agricultural sustainability and intensive production. Nature 2002, 418, 671-677. [CrossRef]

15. Xue, J.; Xie, R.Z.; Zhang, W.F.; Wang, K.R.; Hou, P.; Ming, B.; Gou, L.; Li, S.K. Research progress on reduced lodging of high-yield and-density maize. J. Integr. Agric. 2017, 16, 2717-2725. [CrossRef]

16. Bian, D.H.; Jia, G.P.; Cai, L.J.; Ma, Z.Y.; Eneji, A.E.; Yanhong, Y.H. Effects of tillage practices on root characteristics and root lodging resistance of maize. Field Crops Res. 2016, 185, 89-96. [CrossRef]

17. Wang, Q.; Xue, J.; Chen, J.L.; Fan, Y.H.; Zhang, G.Q.; Xie, R.Z.; Ming, B.; Hou, P.; Wang, K.R.; Li, S.K. Key indicators affecting maize stalk lodging resistance of different growth periods under different sowing dates. J. Integr. Agric. 2020, 19, 2419-2428. [CrossRef]

18. Pellerin, S.; Trendel, R.; Duparque, A. Relationship between morphological characteristics and lodging susceptibility of maize (Zea mays L.). Biotechnol. Agron. Soc. 1990, 10, 439-446.

19. Li, S.Y.; Ma, W.; Peng, J.Y.; Chen, Z.M. Study on yield loss of summer maize due to lodging at the big flare stage and grain filling stage. Sci. Agric. Sin. 2015, 48, 3952-3964.

20. Brune, P.F.; Baumgarten, A.; McKay, S.J.; Technow, F.; Podhiny, J.J. A biomechanical model for maize root lodging. Plant Soil 2018, 422, 397-408. [CrossRef]

21. Robertson, D.J.; Julias, M.; Lee, S.Y.; Cook, D.D. Maize stalk lodging: Morphological determinants of stalk strength. Crop Sci. 2017, 57, 926-934. [CrossRef]

22. Bian, D.H.; Liu, M.Z.; Niu, H.F.; Wei, Z.B.; Du, X.; Cui, Y.H. Effects of nitrogen application times on stem traits and lodging of summer maize (Zea mays L.) in the Huang-Huai-Hai Plain. Sci. Agric. Sin. 2017, 50, 2294-2304.

23. Liu, M.; Qi, H.; Zhang, W.J.; Zhang, Z.P.; Li, X.F.; Song, Z.W.; Yu, J.L.; Wu, Y.N. Effects of deep loosening and nitrogen application on anatomical structures of stalk and lodging in maize. J. Maize Sci. 2013, 21, 57-63.

24. Shi, D.Y.; Li, Y.H.; Zhang, J.W.; Liu, P.; Zhao, B.; Dong, S.T. Effects of plant density and nitrogen rate on lodging-related stalk traits of summer maize. Plant Soil Environ. 2016, 62, 299-306.

25. Zhao, S.C.; Pei, X.X.; He, P.; Zhang, X.Z.; Li, K.J.; Zhou, W.; Liang, G.Q.; Jin, J.Y. Effects of reducing and postponing nitrogen application on soil N supply, plant $\mathrm{N}$ uptake and utilization of summer maize. Plant Nutr. Fert. Sci. 2010, 16, $492-497$.

26. Wang, K.R.; Li, L.L.; Gao, S.; Wang, Y.Z.; Huang, Z.F.; Xie, R.Z.; Ming, B.; Hou, P.; Xue, J.; Zhang, G.Q.; et al. Analysis of main quality index of corn harvesting with combine in China. Acta Agron. Sin. 2021, 47, 2440-2449.

27. Xue, J.; Wang, K.R.; Xie, R.Z.; Gou, L.; Zhang, W.F.; Ming, B.; Hou, P.; Li, S.K. Research progress of maize lodging during late stage. Sci. Agric. Sin. 2018, 51, 1845-1854.

28. Xue, J.; Wang, Q.; Li, L.L.; Zhang, W.X.; Xie, R.Z.; Wang, K.R.; Ming, B.; Hou, P.; Li, S.K. Changes of maize lodging after physiological maturity and its influencing factors. Acta. Agron. Sin. 2018, 44, 1782-1792. [CrossRef]

29. Wei, F.Z.; Li, J.C.; Wang, C.Y.; Qu, H.J.; Shen, X.S. Effects of nitrogenous fertilizer application model on culm lodging resistance in winter wheat. Acta Agron. Sin. 2008, 34, 1080-1085. [CrossRef]

30. Yang, S.M.; Xie, L.; Zheng, S.L.; Li, J.; Yuan, J.C. Effects of nitrogen rate and transplanting density on physical and chemical characteristics and Lodging resistance of culms in hybrid rice. Acta Agron. Sin. 2009, 35, 93-103. [CrossRef]

31. Liu, H.T.; Li, R.Q.; Wang, H.G.; Li, D.X.; Li, H.R. Effect of planting density and nitrogen fertilization rate on lodging resistance and grain yield of strong gluten wheat Gaoyou 2018. J. Triticeae Crops 2017, 37, 1619-1626.

32. Gou, L.; Huang, J.J.; Zhang, B.; Li, T.; Sun, R.; Zhao, M. Effects of population density on stalk lodging resistant mechanism and agronomic characteristics of maize. Acta. Agron. Sin. 2007, 10, 1688-1695.

33. Zheng, X.G.; Xin, R.Z. Determination of nitrogen content of fertilizer by automatic Kjeldahl apparatus. Chem. Anal. Meterage 2014, $23,41-43$.

34. Zhou, D.W.; Chen, J.; She, J.K.; Tong, J.; Chen, Y.X. Temporal dynamics of shearing force of rice stem. Biomass Bioenerg. 2012, 47, 109-114. [CrossRef]

35. Zhang, G.Q.; Ming, B.; Shen, D.P.; Xie, R.Z.; Hou, P.; Xue, J.; Wang, K.R.; Li, S.K. Optimizing grain yield and water use efficiency based on the relationship between leaf area index and evapotranspiration. Agric. J. 2021, 11, 313. [CrossRef]

36. Xue, J.; Gao, S.; Fan, Y.H.; Li, L.L.; Ming, B.; Wang, K.R.; Xie, R.Z.; Hou, P.; Li, S.K. Traits of plant morphology, stalk mechanical strength, and the biomass accumulation in the selection of lodging-resistant maize cultivars. Eur. J. Agron. 2020, 117, 126073. [CrossRef]

37. Feng, G.; Huang, C.L.; Xing, J.F. The research progress in lodging resistance of maize. Crops 2008, 04, 12-14.

38. Xue, J.; Zhao, Y.S.; Gou, L.; Shi, Z.G.; Yao, M.N.; Zhang, W.F. How high plant density of maize affects basal internode development and strength formation. Crop Sci. 2016, 56, 3295-3306. [CrossRef]

39. Wen, X.C.; Wang, X.C.; Deng, X.Y.; Zhang, Q.; Pu, T.; Liu, G.D.; Yang, W.Y. Effects of nitrogen management on yield and dry matter accumulation and translocation of maize in maize-soybean relay-cropping system. Acta Agron. Sin. 2015, 41, 448-457. [CrossRef] 
40. Appenzeller, L.; Doblin, M.; Barreiro, R.; Wang, H.; Niu, X.; Kollipara, K.; Carrigan, L.; Tomes, D.; Chapman, M.; Dhugga, K.S. Cellulose synthesis in maize: Isolation and expression analysis of the cellulose synthase (CesA) gene family. Cellulose 2004, 11, 287-299. [CrossRef]

41. Wang, T.J.; Zhang, L.; Han, Q.; Zheng, F.X.; Wang, T.Q.; Feng, N.N.; Wang, T.X. Effects of stalk cell wall and tissue on the compressive strength of maize. Plant Sci. J. 2015, 33, 109-115.

42. Xue, J.; Gao, S.; Hou, L.Y.; Li, L.L.; Ming, B.; Xie, R.Z.; Wang, K.R.; Hou, P.; Li, S.K. Physiological influence of stalk rot on maize loading after physiological maturity. Agron. J. 2021, 11, 2271.

43. Guo, J.L.; Zhang, Z.M.; Li, B.H. Study on nutrient absorption characteristics of different high-yield summer maize varieties. J. Maize Sci. 1997, 04, 50-52+59.

44. Jin, L.B.; Cui, H.Y.; Li, B.; Yang, J.S.; Dong, S.T.; Zhao, B.; Liu, P.; Zhang, J.W. Effects of integrated agronomic practices on nitrogen efficiency and soil nitrate nitrogen of summer maize. Acta Agron. Sin. 2013, 39, 2009-2015. [CrossRef]

45. Liu, J.; Ning, D.F.; Qin, A.Z.; Sun, B.; Liu, Z.D.; Xiao, J.F.; Ding, P.F.; Zang, H.T.; Zhang, J.Y. Impacts of reducing and delaying nitrogen application on yield and water and nitrogen use efficiency of summer maize under sprinkler fertigation. J. Irrig. Drain. 2020, 39, 42-49. 